\title{
MINERAL AND RAW MATERIALS BASE OF THE URAL FEDERAL DISTRICT: ON THE WAY TO A SUSTAINABLE SUBSOIL USE (USING SOLID COMMERCIAL MINERALS AS AN EXAMPLE)
}

\author{
Irina Gennad'evna Polyanskaya', \\ irina-pol2004@mail.ru \\ Sergey Aleksandrovich Ryl'kov',3, \\ ural@rosnedra.gov.ru \\ Vera Vasil'evna Yurak ${ }^{1,3}$, \\ vera_yurak@mail.ru \\ Vladimir Viktorovich Maslennikov ${ }^{1}$ \\ maslennikov.1950@mail.ru
}

\author{
${ }^{1}$ Institute of Economics of the Ural Branch of RAS \\ Ekaterinburg, Russia \\ ${ }^{2}$ Department for subsoil use \\ of the Ural Federal district (Uralnedra) \\ Ekaterinburg, Russia \\ ${ }^{3}$ Ural State Mining University \\ Ekaterinburg, Russia
}

\begin{abstract}
Relevance. The process of sustainable use of mineral resources, which is one of the priority areas of both rehabilitation, extraction of natural resources, and the state policy in the field of national security, is of particular importance. Currently, the state regulation of subsoil use faces a number of pressing problems: first, the process of recovering the exhaustible resources of solid commercial minerals (SCM) is hampered; secondly, penetration the sixth techno-economic paradigm and the growing "fourth industrial revolution" dictate their terms for organizing a sustainable subsoil use, which implies achieving a balance of common development factors (resource, "green", social, economic ones) using high technologies, artificial intelligence devices, robotics and other innovative solutions. In order to implement sustainable subsoil use at the regional and country levels, it is necessary to diagnose the state of the mineral resources base (MRB). This evaluation can become a functional tool for state regulation of subsoil use.

Purpose of the work is to analyze the state of the mineral resource base of the subsoil use of the Ural Federal District (UFD) from the point of view of fulfilling the condition of balance (security).

Results. The basic principle is defined - the condition for achieving a balance of subsoil use; peculiarities and problems in the management of subsoil use of the Ural Federal District on the basis of the analysis of the Ural Federal District and the system for financing geological exploration in the UFD; some possible directions for meeting the condition for achieving a balance are identified.

Conclusion. The exhaustion of the region's MRB of SCM and the priority of the extraction of fuel and energy raw materials contribute to a reduction in federal funding for the development of the MRB of SCM of the Ural Federal District. The subsoil users of the region are provided with reserves, to some extent, and they are not interested in carrying out further prospecting works. The foregoing demonstrates the need to develop and implement some balanced solutions for further stage of geological study of the MRB of SCM in the framework of public private partnerships using industry regulation mechanisms to achieve a sustainable supply of producers with their own raw materials.
\end{abstract}

Keywords: mineral resource base, solid commercial minerals, Ural Federal District, rehabilitation, geological exploration, sustainable subsoil use, security.

ntroduction

The development of the existing raw materials base, creation of a reserve one of ferrous, non-ferrous, alloying metals (including in the territory of the Ural Federal District) and import substitution by 2020 of a number of metals with its own mineral resources, in accordance with strategic regulatory and legislative acts are research priorities ${ }^{1,2,3,4}$. At the same time, a sustainable development model should represent an economically justified balance between domestic consumption, rehabilitation, export and the necessary import of mineral raw materials ${ }^{5}[1,2]$. This direction is confirmed by the results of analysis of domestic legal acts but various legal sources, the terms "balanced development approach, nature, and subsurface" are used in different contexts and with different meaning ${ }^{6,7,8}[3]$.

In the framework of implementation the substantial subsoil use at the regional and country levels, the analysis was made of the state of the mineral resource base of the Ural Federal District from the perspective of providing basic types of solid minerals. At the same time, the Soviet approach based on the hypothesis of the need to maintain the overall exceeding dynamics of rehabilitation of MRB over the dynamics of mining operations was applied to the construction of a theoretical structure of the balanced subsoil use.

Methodology

To this point, the issues of the methodology for identifying the level of balance of both natural resource use and subsoil use remain the subject of scientific debate $[4,5]$. Nevertheless, there is no doubt that the process of subsoil use should be coordinated with the process of rehabilitation taking into account: domestic needs and export requirements; the need for technical and process

1Sub-program "Mineral wealth management, geological study of subsoil" of the state program "Rehabilitation and use of environmental assets of the Russian Federation": decree of the Government of the Russian Federation of April 15, 2014 No 322 (as amended by RF Government Decree No. 384 of March 31, 2017). Access to ConsultantPlus legal reference system URL: www.consultant.ru

${ }^{2}$ The National Security Strategy of the Russian Federation approved by the Decree of the President of the Russian Federation of 31.12 .2015 No 683 . Access to ConsultantPlus legal reference system URL: www.consultant.ru

${ }^{3}$ The strategy for the development of the geological industry of the Russian Federation until 2030 approved by the decree of the Government of the Russian Federation of June 21, 2010 No 1039-r. Access to ConsultantPlus legal reference system. URL: www.consultant.ru

${ }^{4}$ The forecast of long-term social and economic development of the Russian Federation for the period up to 2030 approved by the Government of the Russian Federation on March 23, 2013. Access to ConsultantPlus legal reference system URL: www.consultant.ru

${ }^{5}$ The strategy of development of the mineral and raw-materials base of the Russian Federation until 2030 (draft). URL: http://mgri.ru/news/strategiya_msb.pdf

${ }^{6}$ On the Concept of Long-Term Social and Economic Development of the Russian Federation for the Period to 2020 (together with the "Concept of Long-Term Social and Economic Development of the Russian Federation for the Period to 2020"): Decree of the Government of the Russian Federation of 17.11.2008 No. 1662-r (as amended on 10.02.2017).

${ }^{7}$ The main activities of the Government of the Russian Federation for the period until 2018 (new version): approved by the Government of the Russian Federation on 14.05.2015.

${ }^{8}$ On the approval of the program for the development of the Russian coal industry for the period up to 2030: decree of the Government of the Russian Federation of June 21, 2014 No. 1099-r. 


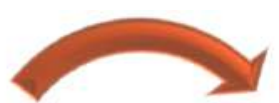

Rehabilitation $\quad$ Subsoil use
of the soil resources

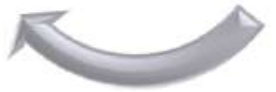

Figure 1. Key elements for achievement a sustainable subsoil use.

Рисунок 1. Условие достижения сбалансированности недропользования.

design details, financial, environmental, information and staff assistance for rehabilitation of the mineral and raw-materials base. Thus, for non-renewable resources (fuel and energy resources (oil, gas, coal) and mineral resources (solid minerals)), the formula for achieving a balance of subsoil use $\left(\mathrm{NP}_{\mathrm{sb}}\right)$ will look like (formula (1)):

$$
\sum_{r=1}^{H} h_{r} \leq \sum_{r=1}^{H} \mathrm{Bo}_{r}
$$

where $\mathrm{I}_{r}$ - rate for use of the $r$-th type of resource; $\mathrm{Vo}_{r}$ - rates of MRB rehabilitation by society; $r$ - type of resource $(r=1 \ldots H)$.

Considering this condition for achieving a balance (security) of subsoil use through the prism of the process approach, it can be concluded that the subsoil use will be balanced only if the subsoil use processes are controlled (managed) and the subsoil resources are rehabilitated (Fig. 1).

The rationale for this principle is based on the analysis of economic regulation of natural resource use as an integral element of state regulation of natural resource use, determining the specifics of the conditions for the balance of subsoil use as an element of sustainable natural resource use; the study of theoretical foundations of rehabilitation of the mineral and raw-materials base, the functioning economic mechanism for regulating subsoil use and rehabilitation of the mineral and raw-materials base in the system of state regulation.

Analysis of the state of mineral and raw-materials base of the Ural Federal District

The current state of the mineral and raw-materials base of the Ural Federal District is legitimate to be considered in comparability with the all-Russian one, which today represents the foundation of the country's economy. Russia is one of the world leaders in the reserves, extraction, and export of a number of solid minerals, including coals, iron ores, nickel, platinoids, gold, phosphates, and others, which play a leading role in the world economy'.

Some specialists in the geological industry [6,7], analyzing the mineral and raw-materials base of Russia, have highlighted in the Draft Strategy for the Development of the Mineral Resources Base of the Russian Federation until 2030 the ${ }^{10}$ following groups of minerals that are characterized by their significance for the country's economy, domestic consumption, scarcity and demand in the market: 1) gold, platinum, diamonds; 2) coal, iron ore, copper, nickel, cobalt, antimony, potassium salts, apatite; 3) lead, zinc, molybdenum, tungsten, chromium, aluminum and some others; 4) manganese, fluorspar, titanium, uranium, zirconium; 5) beryllium, lithium, dispersed elements, tantalum, niobium, tin, rare earth metals and especially pure quartz.

Most of solid minerals belonging to the designated groups, and forming the core of the mineral and raw-materials base of the Ural Federal District, affect the level of socio-economic development. The concentration of developed engineering, energy and mineral resources within the district have been provided the region with competitive advantages for the development of an industrial base for a long period; this base was initially formed on the basis of local mineral resources. Currently, the region provides extraction in Russia: vanadium - more than $90 \%$, bauxite - about $70 \%$, chrysotile-asbestos - more than $60 \%$, iron ore - about $25 \%$, refractory clays - more than 20\% [8]. Coal reserves within the Ural Federal District are concentrated in the Khanty-Mansiysk Autonomous Okrug (KhMAO), Sverdlovsk Region, and Chelyabinsk Region. The balance reserves of coal category A + B + $\mathrm{C}_{1}$ as of 01.01.2017 make up 1067.85 million tons, category $\mathrm{C}_{2}-945.7$ million tons. Non-commercial reserves are estimated at more than 654 million tons $^{11}$. More than $90 \%$ falls on board coal. In KhMAO and Chelyabinsk region, only board coal is on balance, respectively $44.0 \%$ and $46.4 \%$ of the total reserves of the district. In the Sverdlovsk region, coal predominates - slightly more than $8.0 \%$ of the region's reserves.

Own reserves of coal requirements of the Ural Federal District are not covered, which indicates the lack of availability of this type of raw materials. Deliveries of coal to the Ural Federal District are carried out mainly by subsidiaries of holding companies PAO Mechel, OAO UGMK, Evraz Group S.A. from the deposits Kuznetskiy (Kuzbass) and Yuzhno-Yakutsky (Yakutia). A significant amount of coal to cover the needs of metallurgical plants in the Ural Federal District is imported from Kazakhstan.

Potential increase in supplies for metallurgists, power engineers of the Middle and Southern Urals, according to experts of the Department for Subsoil Use of the Ural Federal District "Uralnedra" can be implemented at the expense of energy and soldering coal in the Vorkuta basin, which is of high quality [9]. However, in order to implement this option, it is necessary to solve the transport component identified earlier in the national project "Ural Industrial - Ural Polar".

In the Ural Federal District, the state balance of mineral resources of Russia accounts for 57 deposits of iron ore as of 01.01.2016; their balance reserves amount to 16.7 billion tons - about 15\% of Russia's iron ore reserves. The basis of the region's raw materials base is made up of deposits of titanomagnetite ores. The largest ones are the Gusevogorskoye and Sobstvenno-Kach-

${ }^{9} 2015$, On the state and use of mineral resources in the Russian Federation in 2015: State report of the Ministry of Natural Resources and Environmental Protection of the Russian Federation. Moscow, 344 p.

${ }^{10}$ The strategy of development of the mineral and raw-materials base of the Russian Federation until 2030 (draft). URL.: http://mgri.ru/news/strategiya_msb.pdf

${ }^{11} 2016$, On the state and use of mineral resources in the Russian Federation in 2015: State report / Ministry of Natural Resources. Moscow, p. 6.

132 ПолянскаяИ.Г.идр. Минерально-сырьевая база Уральского федерального округа: на пути ксбалансированномунедропользованию (на примере твердых полезных ископаемых) // Известия УГГУ. 2018. Вып. 3(51). С. 131-141. DOI 10.21440/2307-2091-2018-3-131-141 
kanarskoye in the Sverdlovsk region and the Suroyamskoye in the Chelyabinsk region as well. Ore deposits are complex ones, the major component is titanium. Vanadium, iron, and phosphorus are minors. The iron content in ores is low - 14.5-16.5\%. Within the Ural province, medium and small-scale deposits of skarn-magnetite and sedimentary type have also been identified. The forecasted resources of skarn mineralization in the amount of about 1 billion tons of category $\mathrm{P}_{1}^{12}$ are localized.

The share of titanomagnetite ores is $83.8 \%$ of the total reserves of the region. Titanium-magnetite ores account for more than $87.0 \%$ of the extracted iron ore. In the Ural Federal District, there is a certain disproportion in the region's supply of iron ore for its own metallurgical production. Thus, the enterprises of the Middle Urals are fully provided with magnetite ores of the Northern Urals, as well as titanomagnetite ores of the Gusevogorskoye deposit, the main supplier of raw materials for the Nizhny Tagil metallurgical plant. The Sobstvenno-Kachkanarskoye deposit is at the stage of preparation for development. The construction of the mining enterprise is expected to be completed by 2021.

Metallurgical enterprises of the South Urals are only partially provided with local iron ore. The deficient raw material comes from deposits of the Kursk magnetic anomaly. Directly raw materials come from Kazakhstan (Sokolovsko-Sarbaiskoe ore mining and processing enterprise) for the Magnitogorsk Iron and Steel Company.

The increase in the mineral resources base of iron ore is largely possible due to the development of the Kachkanarsky deposit of titanomagnetite ores. In the Chelyabinsk region, the development of the Suroyamsky titanomagnetite deposit is underway. By the end of 2017, it was planned to begin construction of infrastructure facilities of the mining complex with an annual capacity of 3 million tons of ore; the development of the deposit is expected to begin in 2022. However, everything here is limited by technological problems, since the metallurgy of the South Urals mainly operates on rich magnetite ores ${ }^{13}$.

In 2016, the mineral resources base of iron was expanded due to the placement of reserves of the Serovskoye deposit (Sverdlovsk region) in the amount of 165.6 million tons of $C_{1}+C_{2}$ category, along with nickel and chrome reserves [10].

Nevertheless, in view of the existing need for producers of metallurgy in the South Urals, there remains the need to import iron ore from both other regions (the Kursk Magnetic Anomaly) and from abroad (Kazakhstan). This circumstance indicates a lack of availability of iron ore.

In the deposits of the Southern and Middle Urals, more than 20\% of the domestic copper reserves, mostly of copper-pyrite type, are embedded. On the territory of the Ural Federal District, namely in the Sverdlovsk region, the Volkovskoye medium size field of vanadium-iron-copper ores was discovered (cat. $A+B+C_{1}$ are 1598.4 thousand tons as of 01.01.2016, cat. $C_{2}-15.34$ thousand tons, or $1.8 \%$ of the total Russian balance reserves $\left.{ }^{14}\right)$; the concentration of metal in the ores is $0.64 \%$. Small copper-pyrite and skarn deposits are also known in the region.

In the Chelyabinsk region, one medium (Uzelginskoye) and several small size fields are known; however, copper-porphyry deposits Mikheevskoye (the share in the all-Russian balance reserves - 1.4\%) and Tominskoye (the share in the all-Russian balance reserves $-2.7 \%)^{15}$ are the main ones with poor ores. Total reserves of copper in them exceed 4 million tons. The copper reserves in the ores of a similar type of the explored Birgildinsky deposit are classified as non-commercial one. In the metallogenic zones of the Urals, a significant part of the Russian forecast resources of category P1 is concentrated - 3.4 million tons; almost 0.6 million tons are localized in copper-porphyry ore occurrences, the rest - mainly in objects of copper-pyrite type ${ }^{16}$. Moreover, the state balance in the Sverdlovsk region takes into account four technogenic copper deposits.

Thus, the available copper resource base in the Ural Federal District can hypothetically fully meet the needs of the main producers: OAO Ural Mining and Metallurgical Company (UGMK) and ZAO Russian Copper Company in the period from 5 to 10 years, which indicates the region's own copper raw materials at present. The territorial security is somewhat disrupted because the producers of copper cover their needs for raw materials also due to the deposits they develop in neighboring regions. So, Bashkir Copper Company, a part of the Ural Mining and Metallurgical Company, is developing the copper-pyrite deposits of Podolsk and Severo-Podolsk in the Republic of Bashkortostan, which will be produces as a single minefield by the Podolsky underground mine. It is planned to begin mining operations not later than $2022^{17}$. ZAO Russian Copper Company is supplied with raw materials from the Gayskoe deposit in the Orenburg region with 4.8 million tons of copper reserves.

In the future, it is also planned to develop the Tominskoe copper-porphyry deposit in the Chelyabinsk region on the basis of a mining and processing plant with a production capacity of 28 million tons of ore per year, included in the "Strategy for the development of non-ferrous metallurgy in Russia for 2014-2020 and until 2030"18. However, environmental problems that have already provoked a negative reaction from the local population can be an obstacle to the implementation of this project.

With the current level of production, the availability of active supplies of copper to the main suppliers of raw materials to the Ural Federal District (the Republic of Bashkortostan, the Orenburg and Chelyabinsk regions) is 47 years. In the region, there is a significant reserve of forecast resources $\mathrm{P}_{1}+\mathrm{P}_{2}-$ more than 5 million tons [11]. Further development of the copper resource base is related to the continuation of the development of copper-porphyry ores of the South Urals, as well as the possible resumption of geological exploration in the Polar Urals.

Almost $30 \%$ of the Russian reserves (433 million tons) of ${ }^{19}$ sedimentary bauxites in carbonate rocks in the large Cheremukhovsky and medium-sized Krasnaya Shapochka, Kalinsky and Novo-Kalinsky fields located in the North Ural bauxite-bearing region are concentrated - the highest quality in the country with a high content of $\mathrm{Al}_{2} \mathrm{O}_{3}(54-56 \%)$ and a high silica module. However, they cannot compete in quality with the deposits being developed abroad, both in terms of mineral composition, depth of occurrence, and the geological and climatic conditions of development ${ }^{20}$.

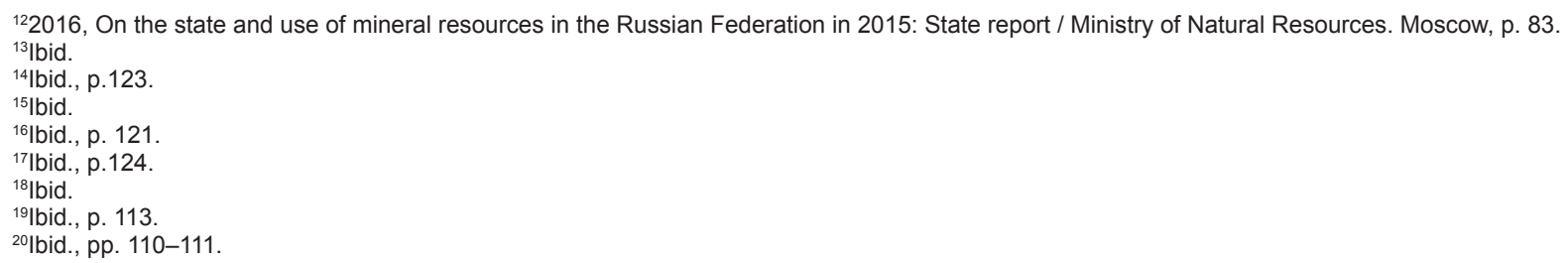

Полянская И. Г. и др. Минерально-сырьевая база Уральского федерального округа: на пути к сбалансированному недропользо- 133 ванию (на примере твердых полезных ископаемых) // Известия УГГУ. 2018. Вып. 3(51). С. 131-141. DOI 10.21440/2307-2091-2018-3-131-141 
In the Ivdelsky bauxite-bearing region, 10.6 million tons of forecast bauxite resources of category $\mathrm{P}_{1}$ and 10.9 million tons of $\mathrm{P}_{2}$ category are located. The quality of bauxite is low. Further development of the raw materials base of alumina production is hindered by complex mining and geological conditions of occurrence. The development of deposits of OAO SUBR is carried out by an underground method at depths of up to $1.12-1.3 \mathrm{~km}$. In 2015, OAO Sevuralboksitruda has commissioned the first startup complex of the mine Cheremukhovskaya-Glubokaya with a depth of $1550 \mathrm{~m}$. Years of reserves for the mine are for at least 40 years; it will be able to provide alumina refinery plants of RUSAL company in the Sverdlovsk region (Bogoslovskiy and Ural ones), as well as the enterprises of the cement and refractory industries with local bauxite raw materials for the near future.

Almost 14\% of Russian gold reserves are in the deposits of the Ural metallogenic province. Mostly, it is secondary gold in the ores of copper-pyrite deposits. Gold-sulfide-quartz ores associated with intrusive bodies (Berezovskoye in the Sverdlovsk region) and gold-sulfide-quartz ores localized in terrigenous strata (Svetlinskoye, Yuzhnyi Kurosan in the Chelyabinsk region) are distinguished among the gold deposits. The gold content in these ores varies from 1.9 to 17 ppm. Prospects for increasing the gold reserves of the Ural province are related primarily with the discovery of new gold-sulfide-quartz deposits as well as gold-copper-porphyry ones; forecast resources of category $\mathrm{P}_{1}$ provinces are estimated to be more than 400 tons ${ }^{21}$.

The main producers of gold at the gold ore deposits are:

- in the Sverdlovsk Region: OOO Berezovskoye Rudoupravlenie with a production level of 0.7 tons as of 01.01.2016 and ZAO Zoloto Severnogo Urala with a production level of 3.8 tons as of 01.01.2016;

- in the Chelyabinsk region: AO Yuzhuralzoloto Group of Companies and AO Vostochnaya with a total production level of 6.8 tons as of 01.01.2016.

Another major producer of this noble metal is the holding company OAO Ural Mining and Metallurgical Company (UGMK). At the enterprises of this company gold is extracted and its refining is carried out from complex copper-bearing ores of the Sverdlovsk and Chelyabinsk regions, as well as at the enterprises located outside the Ural Federal District (OAO Gaisky Mining and Processing Plant, OAO Bashkirskaya Copper, ZAO Urupsky Mining and Processing Plant, etc.); this provides about $4 \%$ of Russian gold production ${ }^{22}$. In the medium term, with the current volume of production, the region is provided with this type of minerals.

In the Ural Federal District, chromite reserves were identified in the Yamal-Nenets Autonomous District, the Sverdlovsk and Chelyabinsk Regions. In the Yamalo-Nenets Autonomous District, two deposits have been explored within the Rai-Iz massif; they together account for $9 \%$ of the chrome ore reserves of the country. The forecasted resources of chromites in the region with a very high degree of confidence are $21 \%$ of the Russian ones. They are localized in the massifs of Ray-Iz (24.4 million tons) and Voikaro-Sinyinsky (5.2 million tons). In the Sverdlovsk and Chelyabinsk regions, the small chromite deposits totaled only 0.3 million tons as of 01.01.2016, or less than $1 \%$ of the Russian deposits. In 2016, a significant increase in the chromite resource base was due to the supply of 7.98 million tons of chromium ore category $\mathrm{C}_{1} \mathrm{C}_{2}[10]$ at the Serovsky deposit (Sverdlovsk region) along with iron and nickel reserves of similar categories, which significantly reduces deficiency for consumers of chrome ores in the district (Chelyabinsk electrometallurgical works, Klyuchevskoy and Serovsky ferroalloys works). Still, the need for raw materials is not fully covered by own resources. There is a need for import from Kazakhstan (more than half of the consumption in Russia as a whole).

Further growth in chromite reserves in the Sverdlovsk and Chelyabinsk regions is possible due to the forecast resources of category $\mathrm{P}_{1}$, which total 4 million tons ${ }^{23}$. Bringing into development of Zapadnoye (Yamalo-Nenets Autonomous Okrug) and Yuznoye Saranskoye deposits in the neighboring Perm region is considered to be topical. It should be noted that the development of all designated deposits still cannot cover the formed requirements for chromites.

Thus, the provision of the region with chrome raw materials cannot be considered sufficient for a long-term perspective. In this regard, it remains necessary to carry out measures to increase existing capacities for the extraction of raw materials and expand its mineral and raw materials base through the possible continuation of prospecting works in the Subpolar Urals.

In the Ural Federal District, 44.7 million tons of manganese ore reserves (slightly more than $19 \%$ of Russian ones) and 22.2 million tons of $\mathrm{P}_{1}$-category resources $(9.6 \%)$ are ${ }^{24}$ concentrated within the same metallogenic province. The overwhelming part of the reserves of manganese ores of the region and half of the forecast resources of high reliability are concentrated in nine deposits of carbonate ores of the North Ural ore region in the Sverdlovsk region. Another small deposit of oxidized ores, as well as a promising area of their development, has been identified in the Chelyabinsk region.

Currently, the territory of the Ural Federal District does not produce manganese raw materials. It was terminated due to economic inefficiency in 1964. The main problem of using the manganese mineral resource base is the low quality of manganese ore, which is represented by ordinary and poor mainly carbonate rebellious ore with a high content of harmful impurities - iron and phosphorus, complex texture-structural features, variability of the material composition. A required condition for starting operation of manganese fields is the implementation of new methods for their processing.

In the region, manganese alloys, which are an essential component for metallurgy, are produced by the Chelyabinsk electrometallurgical works and the Satkinsky ironworks. Raw materials for producers are almost completely supplied from abroad (Kazakhstan and South Africa). As for manganese is concerned, a situation similar to chromium is observed: insufficient supply of this type of raw material.

Results and conclusions on the analysis of the mineral resource base of the Ural Federal District. Thus, the proximate analysis of the state of the mineral and raw materials base of the main types of solid minerals in the Ural Federal District makes it possible to draw the following conclusions about the supply of its producers with its own raw materials (Table):

- on the one hand, we can state the availability of certain types of solid minerals, and on the other hand, the presence of their deficit due to economic unprofitable development and poor quality of raw materials;

- the need for such types of minerals as iron ore, copper, and coal, which in general in Russia do not belong to the scarce; they are not fully covered;

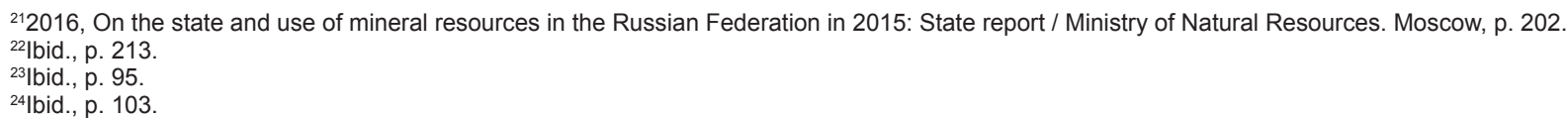

134 Полянская И. Г. идр. Минерально-сырьевая база Уральского федерального округа: на пути к сбалансированному недропользованию (на примере твердых полезных ископаемых) // Известия УГГУ. 2018. Вып. 3(51). С. 131-141. DOI 10.21440/2307-2091-2018-3-131-141 


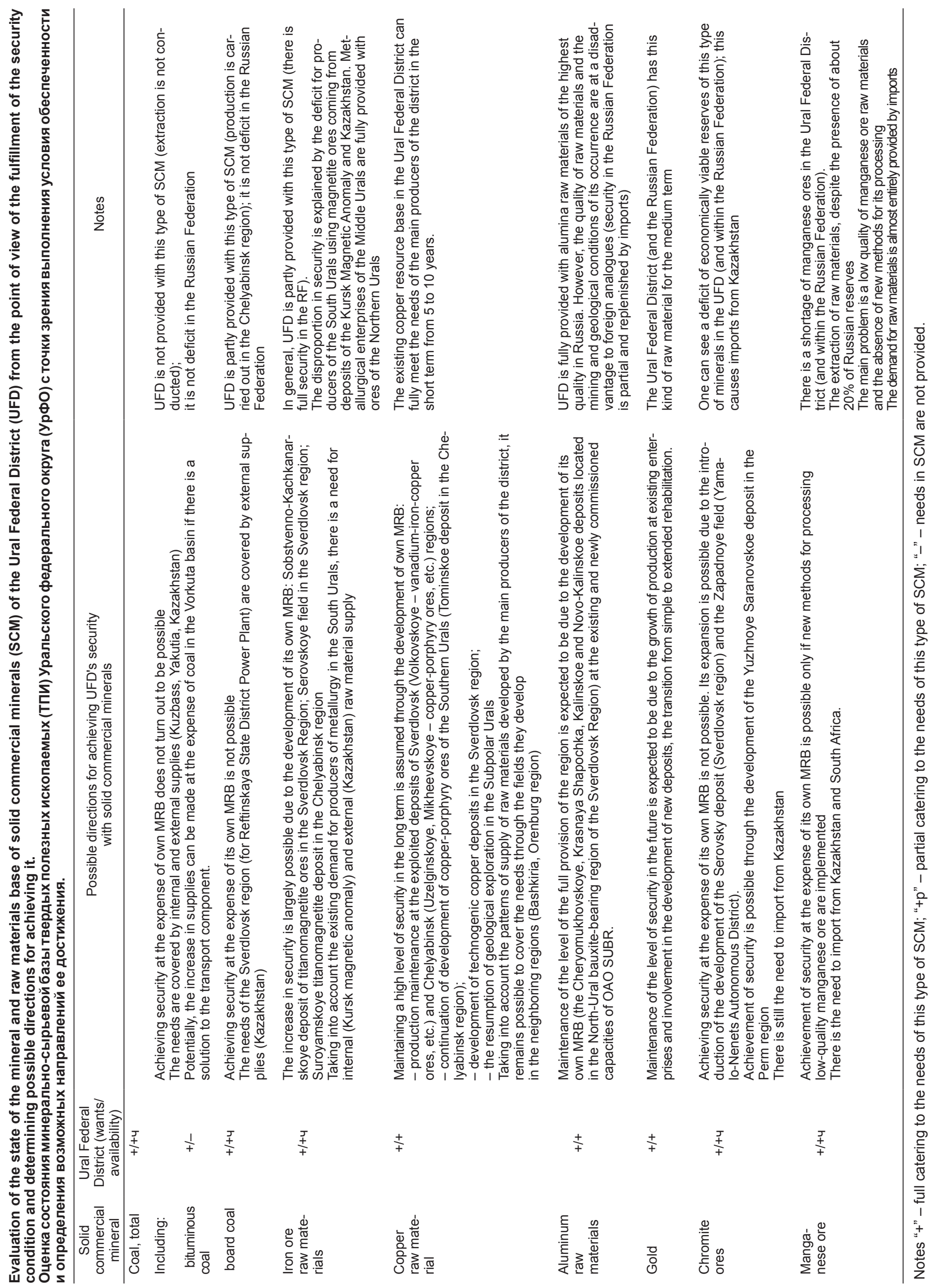


- the mineral and raw materials base of coal is practically exhausted; mining of coal is not conducted, development of its available small reserves is economically unprofitable; coal needs of the metallurgical works of the region are mainly covered by supplies from the Kuzbass and Yakutia deposits, as well as imports from Kazakhstan;

- the presence of significant reserves of iron ore and copper raw materials does not fully satisfy the needs of producers with the corresponding products;

- the disproportion in the supply of iron ore is explained by the deficit for producers of the South Urals using magnetite ores, which are eliminated by supplies from the deposits of the Kursk Magnetic Anomaly and Kazakhstan; metallurgical enterprises of the Middle Urals are fully provided with magnetite ores of the Northern Urals;

- the available copper resource base can fully meet the needs of the main producers of the district in the short term from 5 to 10 years. At the same time, copper producers partially cover their needs due to the deposits they develop in neighboring regions (Bashkiria, Orenburg region);

- significant reserves of the North-Ural bauxite-bearing region accounting for about $30 \%$ of Russian ones are fully supplied with alumina raw materials, the highest-quality in Russia. However, the quality of raw materials and the geological conditions of its occurrence is at a disadvantage to foreign analogs;

- the demand of producers in chromic raw materials is not fully covered by own resources; there is the need to import from Kazakhstan for more than half of consumers in Russia as a whole;

- the need for manganese raw materials is almost completely provided by imports from Kazakhstan and South Africa; the extraction of raw materials is not carried out, despite the concentration of more than 19\% of Russian manganese ore reserves mainly in the Sverdlovsk and Chelyabinsk regions; the main problem is the low quality of manganese ore raw materials and the absence of new methods for its processing.

A prerequisite for solving the problem of increasing the availability of the region by the main types of solid minerals is the rehabilitation of their depleted mineral resources base, which has previously been highly studied. The initial stage for rehabilitation of the mineral resources base is geological prospecting works. In order to study the issue of organization of sustainable subsoil use in the territory of the Ural Federal District, the state of activities for the implementation of geological exploration in the Ural Federal District was considered from the point of view of financial security.

Analysis of financing for geological exploration in the Ural Federal District. In the Ural Federal District, in the structure of total costs for the type of geological exploration, which includes all the types of minerals (without limitation, hydrocarbons), the greatest share is accounted for exploration and prospecting.

In 2017 , exploration work accounted for $55.1 \%$, which is $2.8 \%$ lower than in 2016; prospecting works $-32.4 \%$, level increase (2016) - 6\% (Fig. 2).

Since 2010, exploration financing has a slight upward trend. The largest amount of financing accounted for 2015 - 74283.6 million rubles; in 2017, its value fell to 54265.2 million rubles. The volume of financing for this period of prospecting works slightly increased from 16289.9 million rubles in 2010; and 31941.3 million rubles in 2017. The largest amount of funding for prospecting was 41803.9 million rubles in 2015 (Fig. 3).

The share of other types of geological prospecting remains at a low level. 1-2\% of the total funding of geological exploration accounts for regional work, more than $80 \%$ of which $(2016-83.1 \%, 2017-85.9 \%)$ is financed from the federal budget. Research and advanced development financing remains quite insignificant (in $2016-4.3 \%$, in 2017 - 3.4\%), as well as thematic and experimental-methodical work $(2016-3.5 \%, 2017-4.7 \%)$ of the total funding. All expenses for research and advanced development

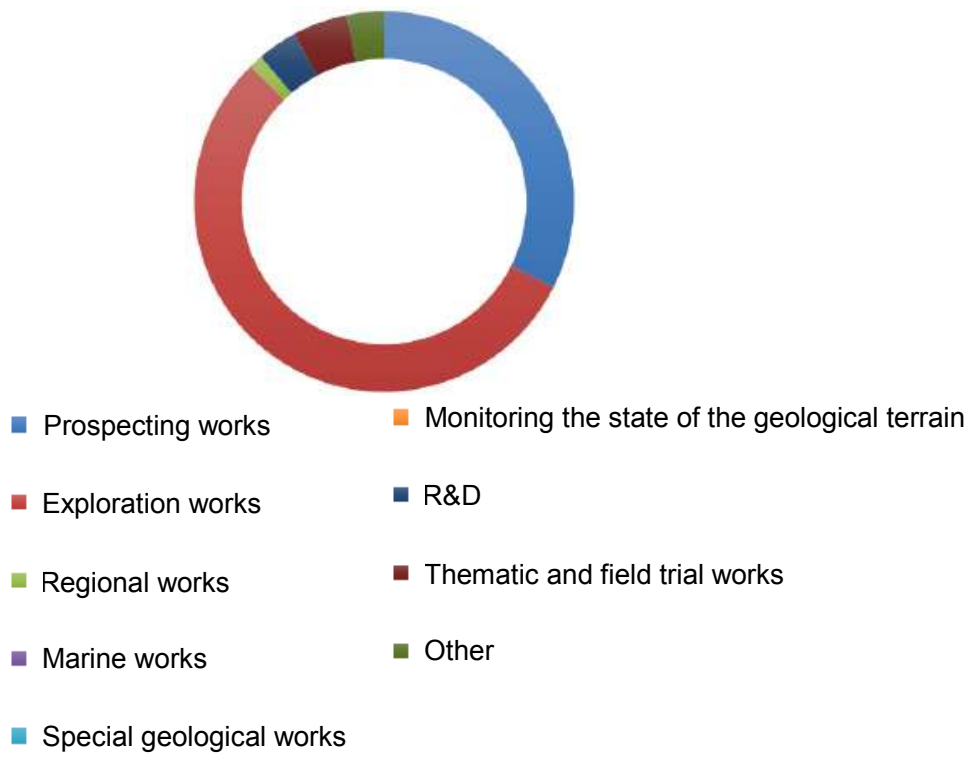

Figure 2. Total costs by types of geological exploration in the Ural Federal District in 2017 for all types of minerals, $\%{ }^{25}$. Рисунок 2. Общие затраты по видам ГРР в УрФО в 2017 г. по всем видам полезных ископаемых, \% ${ }^{25}$.

\footnotetext{
${ }^{25}$ Calculated according to the data of the subjects included in the Ural Federal District (Sverdlovsk, Kurgan, Tyumen, Chelyabinsk regions, KhMAO-Yugra, YamaloNenets Autonomous District) in accordance with the statistical reporting forms No. 2-GR "Information on the implementation of geological exploration" and form 7-GR "Information on implementation of geological exploration by their types and groups of minerals". The data was provided by the Department for Subsoil Use for the Ural Federal District (Uralnedra).
} 


$\rightarrow$ Prospecting works
$\rightarrow$ Regional works
$\rightarrow$ Marine works
$\rightarrow$ Works of a special
geological purpose
State monitoring
of geological environment
$\rightarrow$ Research and Advanced
Develonment
$\rightarrow$ Thematic and field trial
works
$\because$ Other prospecting surveys

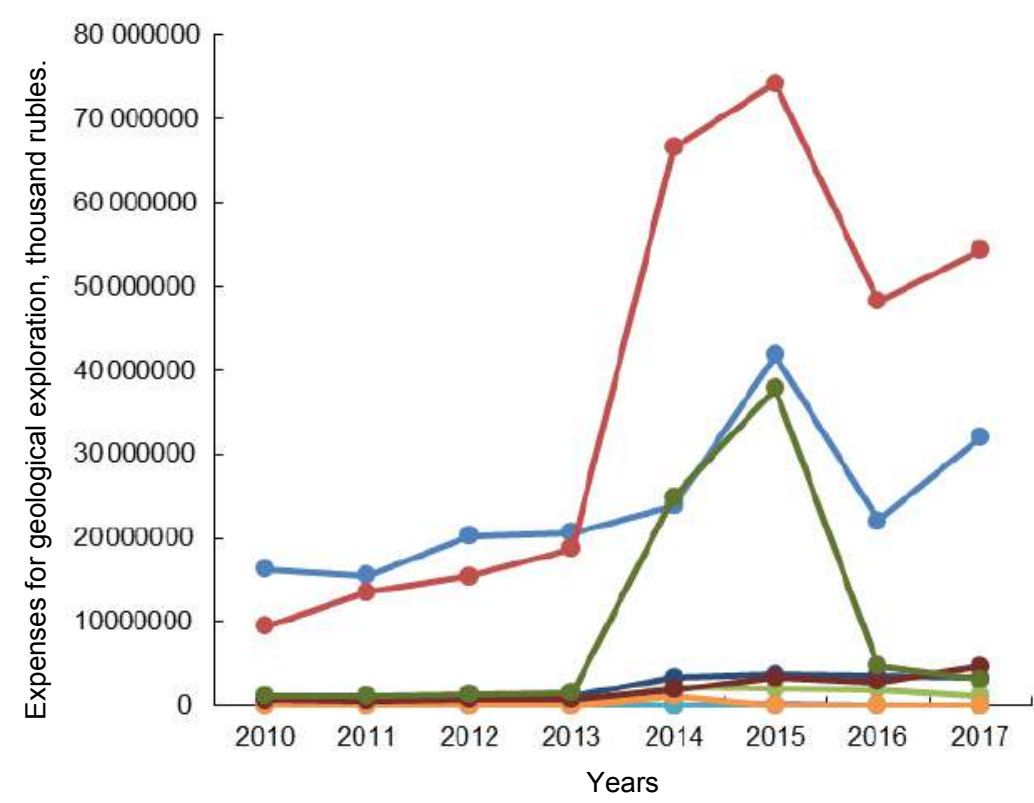

Figure 3. Total costs for types of geological exploration in the Ural Federal District in 2010-2017 for all types of minerals, thousand rubles ${ }^{26}$. Рисунок 3. Общие затраты по видам ГРР в УрФО в 2010-2017 гг. по всем видам полезных ископаемых, тыс. руб. ${ }^{26}$

were due to own resources of subsoil users. In 2017, there were no funds from the federal budget for thematic and methodological work, although in 2016, the share of federal funds for this type of work was 5.8\%. In 2016 and 2017, there was no funding for maritime work (in 2015, funding was provided from the budget) and special geological work. Costs for monitoring the state of the geological terrain in 2016 were not carried out; in 2017, less than 4.0 million rubles was spent in KhMAO-Yugra.

It should be noted that an irretrievable situation with the financing of research and advanced development is characteristic not only of the Ural Federal District. According to the results of the Federal Agency for Subsoil Use in 2016, the structure of costs for sub-program "Rehabilitation of mineral resources base, geological study of subsurface resources" of the State program "Rehabilitation and use of environmental assets of the Russian Federation" for scientific and technological support of geological exploration work was only $0.12 \%$ (42 million rubles.). At the same time, $23 \%$ of costs accounted for geological exploration of solid commercial minerals; hydrocarbon raw materials - 54\% [10].

The share of solid commercial minerals is very low in total costs of geological exploration of the UFD. In 2017, it was: ferrous, non-ferrous, alloying metals $-2.2 \%$; noble metals $-2.5 \%$; non-metals $-1.7 \%$. The largest specific weight is fuel and energy resources $-93.6 \%$ (Fig. 4).

A similar trend has been observed during the period 2010-2017 (Fig. 5, 6).

Analyzing the sources of financing of general geological exploration for all types of minerals, we have to state that the greatest share belongs to the own resources of subsoil users. In 2017, they accounted for about $95 \%$ of the total funding.

About $1.5 \%$ were funds from the federal budget; $2.0 \%$ - funds of domestic and foreign investors; $1.5 \%$ - loans; less than $1 \%$ - means of the subjects of the Federation that are members of the Ural Federal District. With minor variations, the current trend is observed for the period 2010-2017 (Fig. 7, 8). The situation in the Ural Federal District is comparable to the overall situation in Russia. The volume of financing the rehabilitation of the mineral resources base at the expense of subsoil users in Russia in 2016 far exceeded (882\%) financing from the federal budget and amounted to 295 billion rubles. Solid commercial minerals among them accounted for $12 \%$ (35 billion rubles with excess of 580\%) [10].

Out of the total volume of own funds of subsoil users of the UFD invested in the geological exploration in 2017, amounting to 71410.6 million rubles, $98.5 \%$ are accounted for KhMAO-Yugra and Yamal-Nenets Autonomous District, where the majority of the UFD fuel and energy resources are concentrated, and only 1.5\% of the subsoil users own funds were directed to geological exploration for solid minerals.

Smaller funds out of the total costs allocated from the federal budget for geological exploration in 2017 are for fuel and energy resources - about 77\%; solid commercial minerals account for slightly more than $23 \%$. However, the share of total costs for geological exploration on solid commercial minerals is insignificant. In 2017, it was: ferrous, non-ferrous, alloying metals - $2.2 \%$; noble metals $-2.5 \%$; non-metals $-1.7 \%$. The largest specific weight is fuel and energy resources $-93.6 \%$.

Results and conclusions on the analysis of financing of geological exploration in the Ural Federal District. Thus, the situation with financing of geological exploration in the Ural Federal District shows (along with its insignificant absolute values) the decrease in the level of expenditures from the budget of the Russian Federation, the budgets of the subjects of the Russian Federation and the increase in the share of costs from subsoil users. At the same time, the share of exploration costs for solid mineral resources in total costs is slightly more than $6.0 \%$; the rest is related to fuel and energy resources.

When considering the status of exploration process in the Ural Federal District, it is impossible not to draw attention to a problem that has been the subject of scientific debate for a long time [12-15], but still relevant to this day, namely:

${ }^{26}$ Calculated according to the data of the subjects included in the Ural Federal District (Sverdlovsk, Kurgan, Tyumen, Chelyabinsk regions, KhMAO-Yugra, YamaloNenets Autonomous District) in accordance with the statistical reporting forms No 2-GR "Information on the implementation of geological exploration" and form 7-GR "Information on implementation of geological exploration by their types and groups of minerals". The data was provided by the Department for Subsoil Use for the Ural Federal District (Uralnedra). 


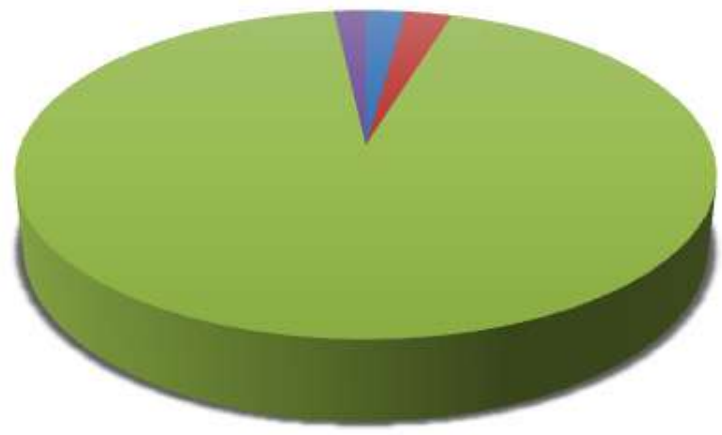
- Noble metals and diamonds
- Fuel and energy raw materials
non-metals

- Ferrous, non-ferrous, alloying, rare metals - total

Figure 4. Structure of common costs for geological exploration in the Ural Federal District in 2017 by types of minerals, $\%{ }^{27}$. Рисунок 4. Структура общих затрат на ГРР в УрФО в 2017 г. по видам полезных ископаемых, \% ${ }^{27}$.

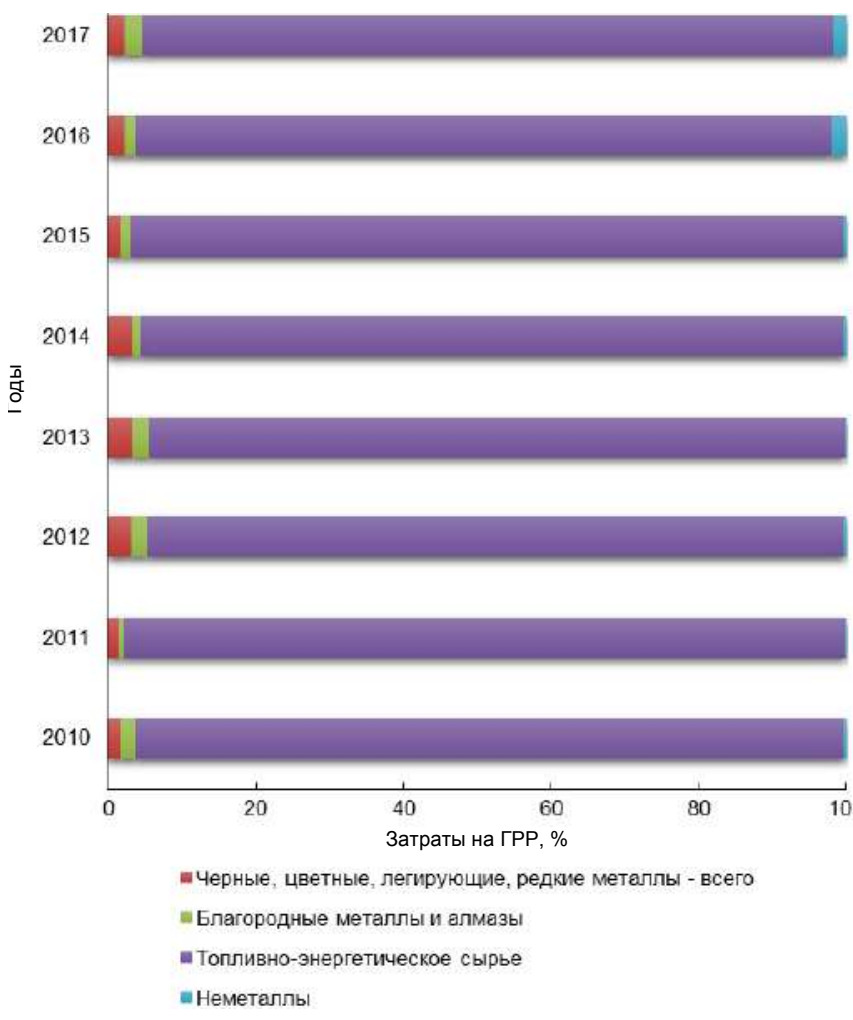

Figure 5. The structure of common costs for geological exploration in the Ural Federal District in 2010-2017 by types of minerals ${ }^{28}$ Рисунок 5. Структура общих затрат на ГРР в УрФО в 2010-2017 гг. по видам полезных ископаемых ${ }^{28}$.

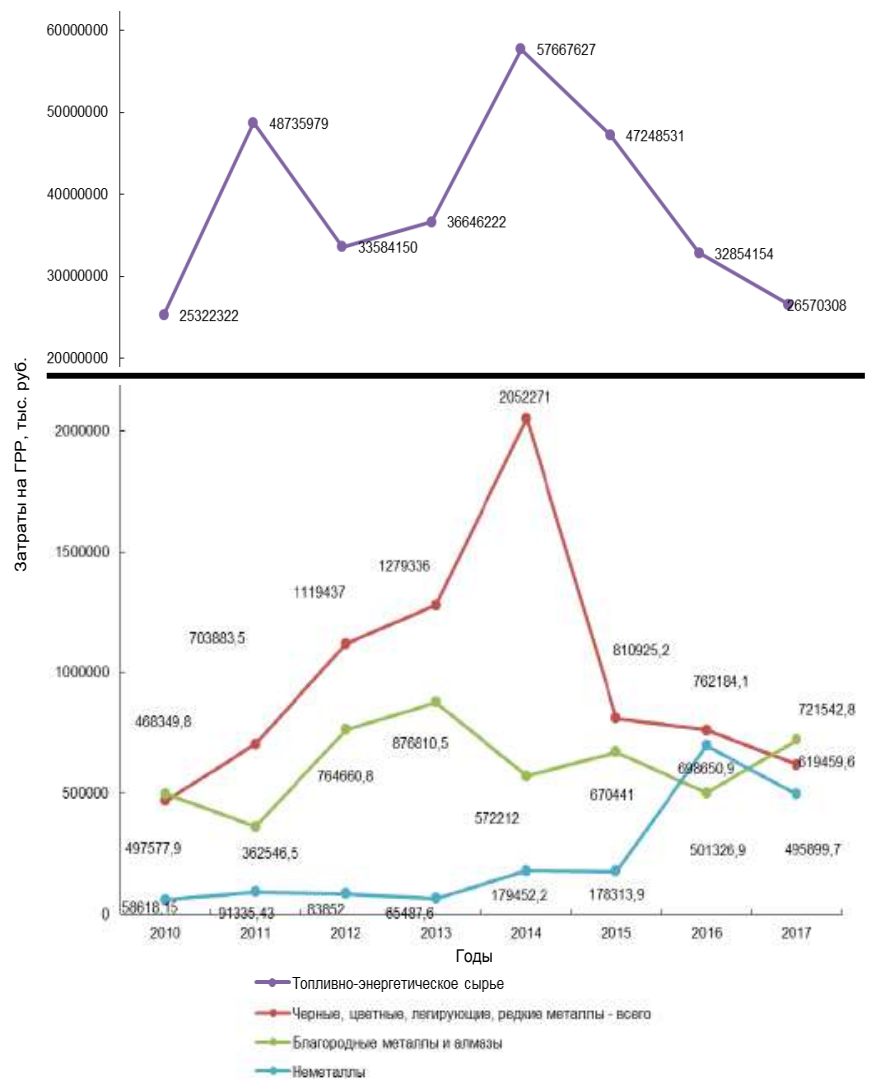

Figure 6. Total costs for geological exploration in the Ural Federal District in 2010-2017 by types of minerals ${ }^{29}$.

Рисунок 6. Общие затраты на ГРР в УрФО в 2010-2017 гг. по видам полезных ископаемых ${ }^{29}$.

${ }^{27}$ Calculated according to the data of the subjects included in the Ural Federal District (Sverdlovsk, Kurgan, Tyumen, Chelyabinsk regions, KhMAO-Yugra, YamaloNenets Autonomous District) in accordance with the statistical reporting forms No 2-GR "Information on the implementation of geological exploration" and form 7-GR "Information on implementation of geological exploration by their types and groups of minerals". The data was provided by the Department for Subsoil Use for the Ural Federal District (Uralnedra).

${ }^{28} \mathrm{lbid}$.

${ }^{29} \mathrm{bid}$

138 Полянская И. Г. идр. Минерально-сырьевая база Уральского федерального округа: на пути к сбалансированному недропользованию (на примере твердых полезных ископаемых) // Известия УГГУ. 2018. Вып. 3(51). C. 131-141. DOI 10.21440/2307-2091-2018-3-131-141 


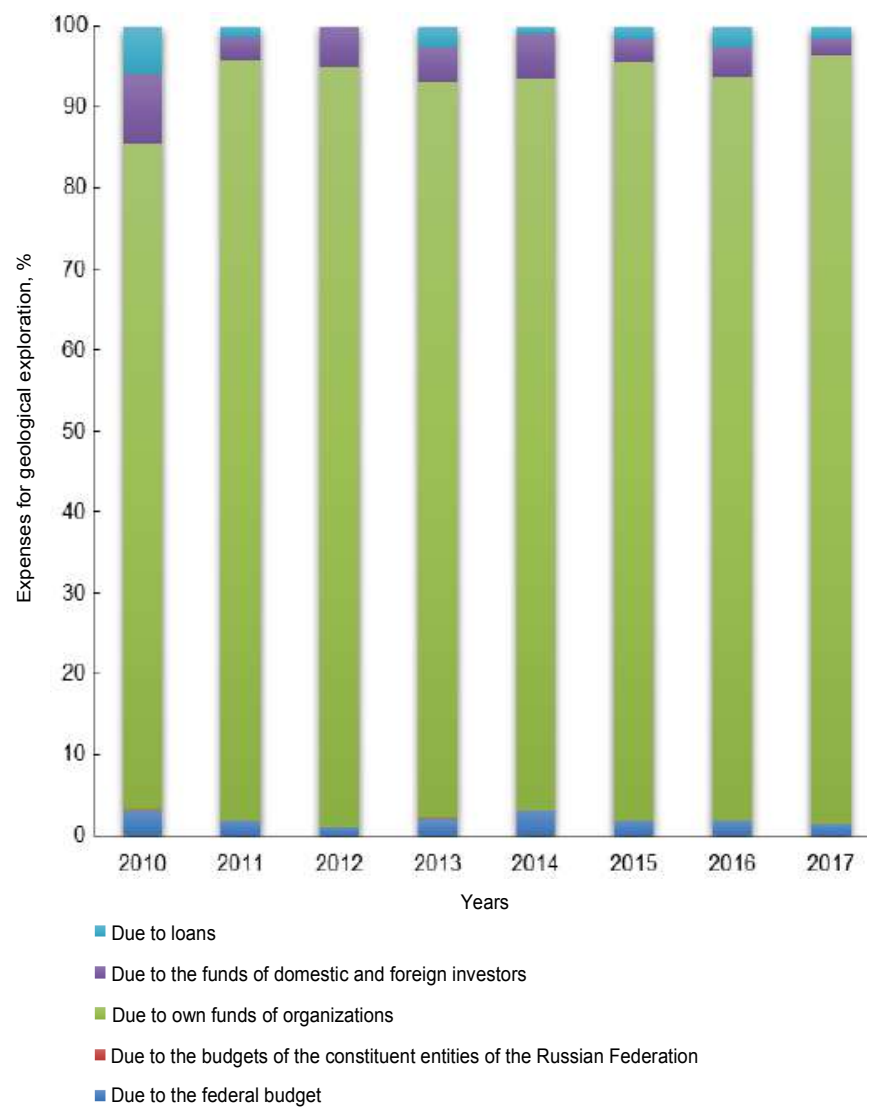

Figure 7. Structure of sources of financing of total costs for geological exploration in the Ural Federal District in 2010-2017 for all types of minerals ${ }^{30}$.

Рисунок 7. Структура источников финансирования общих затрат на ГРР в УрФО в 2010-2017 гг. по всем видам полезных ископаемых ${ }^{30}$.

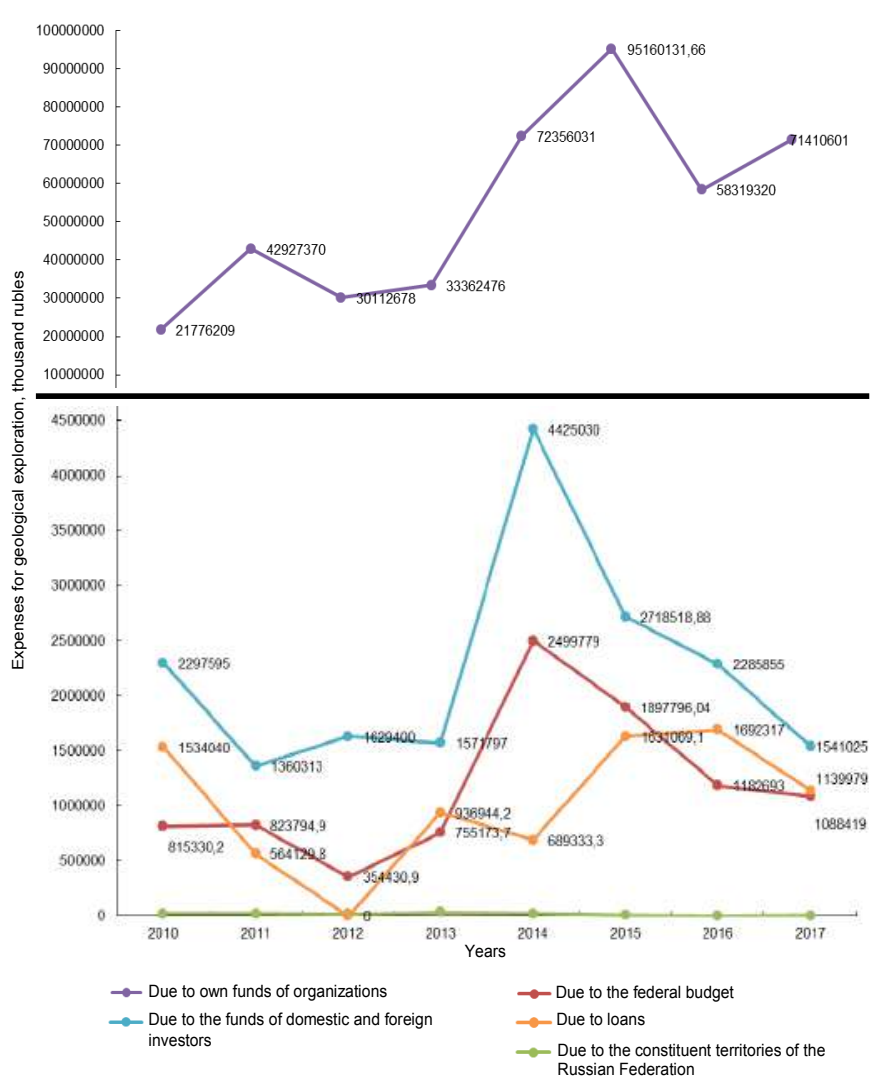

Figure 8. Distribution of costs for geological exploration work on sources of financing in the Ural Federal District in 2010-2017 for all types of minerals ${ }^{31}$.

Рисунок 8. Распределение затрат на ГРР по источникам финансирования в УрФО в 2010-2017 гг. по всем видам полезных ископаемых ${ }^{31}$.

- low financial security;

- exhaustion of economically viable reserves of significant exploitable deposits;

- depletion of the search reserve (the fund of prepared prospective geological sites);

- lack of advanced technologies for the enrichment and processing of primary raw materials;

- dependence on imports of concentrates;

- low level of support and maintenance of the branch geological prospecting science providing efficiency of carrying out prospecting and geological works;

- lack of an effective organizational and economic structure and mechanism for implementation of activities for the rehabilitation of mineral resources, including the interaction of the state, science and business.

Taking into account the depletion of the mineral and raw materials base of the solid commercial minerals of the region, and the fact that the Siberian and Far Eastern regions with their hydrocarbon reserves are promising regions for development of geological exploration, help from the federal budget's side was not forthcoming (concerning the development of the mineral resource base of the solid minerals of the Ural Federal District). The subsoil users of the region are provided with reserves to some extent; they are not interested in carrying out further prospecting works. The information above demonstrates the need to develop and implement some weighted solutions to the further stage of geological study within the framework of public-private partnerships using industry regulation mechanisms in order to achieve balanced supply of the region's producers with its own raw materials.

One of the vectors for the development of this direction can be considered as the option of returning to the question of the need for a meridional transport corridor along the Urals with access to the Arctic. But acceleration of this process places a special responsibility on researchers due to the extreme importance of the decisions made [16, 17].

The study was prepared with the financial support of the Russian Academy of Sciences Project No. 18-6-7-42 "Socio-economic development of the Arctic zone of the Urals: opportunities, priorities and prospects for spatial development".

\section{REFERENCES}

1. Tjiptabudy J. 2014, The application of the balance principal in the natural resources management in marine and coastal areas. Mimbar Hukum, no. 26 (2), pp. 285-296.

2. Herbohn K., Herbohn J., Hartebrodt C., Smith C. 2013, Using a Balanced Scorecard to Improve the Management of Natural Resources: Experiences from Baden-Württemberg. Society \& Natural Resources: An International Journal, no. 26 (8), pp. 865-882. DOI 10.1080/08941920.2012.719999. 
3. Marimin M., Wibisono A., Darmawan M. A. 2017, Decision Support System for Natural Rubber Supply Chain Management Performance Measurement: A Sustainable Balanced Scorecard Approach. International Journal of Supply Chain Management. No 6 (2). P. 60-74.

4. Connell J. 2018, Islands: balancing development and sustainability? Environmental Conservation, pp. 1-14. DOI 10.1017/S0376892918000036.

5. Reilly J. M. 2012, Green Growth and the Efficient Use of Natural Resources. Energy Economics, no. 34, pp. 85-93.

6. Natalenko A. E., Park V. A., Stavsky A. P. 2015, Osnovnyye napravleniya razvitiya mineral'no-syr'yevoy bazy Rossiyskoy Federatsii [The main areas of development of the mineral and raw materials base of the Russian Federation]. Mineral'nyye resursy Rossii. Ekonomika i upravleniye [Mineral Resources of Russia. Economics and Management], no. 1, pp. 2-9.

7. Karpuzov A. F., Tarasov A. V. 2015, Strategicheskiye vektory razvitiya mineral'no-syr'yevoy bazy Rossiyskoy Federatsii na sovremennom etape (vybor puti) [Strategic vectors for the development of the mineral resources base of the Russian Federation at the present stage (path choice)]. Mineral'nyye resursy Rossii. Ekonomika i upravleniye [Mineral Resources of Russia. Economics and Management], no. 6, pp. 2-12.

8. Ryl'kov S. A. 2016, Prirodno-resursnyy potentsial Ural'skogo FO [Natural and resource potential of the Ural Federal District]. Razvedka i okhrana nedr [Prospect and protection of mineral resources], no. 9, pp. 30-33.

9. Parfyonov S. A. 2009, Sever nado pisat's bol'shoy bukvy [The North should be written with a capital letter]. Ural [The Urals], no. 8, pp. 204-212. 10. 2017, Ministry of Environment Protection and Natural Resources of the Russian Federation. Federal Agency for Subsurface Use. Results of the Federal Agency for Subsurface Use in 2016 and plans for 2017: information-analytical materials. Moscow, 58 p.

11. 2016, Ivanov A. I., Vartanyan S. S., Chernykh A. I., Volchkova A. G., Kuznetsov V. V., Seravina T. V. Sostoyaniye i perspektivy razvitiya MSB medi, tsinka i svintsa Rossii [State and perspectives of the development of the mineral resources base of copper, zinc and lead of Russia]. Razvedka i okhrana nedr [Prospect and protection of mineral resources], no. 9, pp. 95-100.

12. Mikhailov B. K. 2016, Osnovnyye prioritety i pokazateli razvitiya mineral'no-syr'yevoy bazy tverdykh poleznykh iskopayemykh v strategicheskikh dokumentakh geologicheskoy otrasli [The main priorities and indicators of the development of the mineral resources base of solid commercial minerals in strategic documents of the geological industry]. Mineral'nyye resursy Rossii. Ekonomika i upravleniye [Mineral Resources of Russia. Economics and Management], no. 5, pp. 25-29.

13. Melekhin E. S., Dudukov M. V. 2016, Pravovyye problemy privlecheniya investitsiy v vosproizvodstvo mineral'no-syr'yevoy bazy strany [Legal problems of attracting investment in the reproduction of the mineral and raw materials base of the country]. Mineral'nyye resursy Rossii. Ekonomika i upravleniye [Mineral Resources of Russia. Economics and Management], no. 1 (1), pp. 80-82.

14. Ageeva S. D., Kryukov V. A. 2016, Sistema nedropol'zovaniya $v$ Rossii - kakoy yey byt'? [The system of subsoil use in Russia - what should it be?]. Mineral'nyye resursy Rossii. Ekonomika i upravleniye [Mineral Resources of Russia. Economics and Management], no. 2, pp. 80-87.

15. Mikhailov B.K. 2017, Rol'gosudarstva v razvitii mineral'no-syr'yevoy bazy tverdykh poleznykh iskopayemykh $v$ strategicheskikh dokumentakh geologicheskoy otrasli [The role of the state in the development of the mineral resources base of solid commercial minerals in strategic documents of the geological industry]. Mineral'nyye resursy Rossii. Ekonomika i upravleniye [Mineral Resources of Russia. Economics and Management], no. 2, pp. 33-35.

16. Dushin A. V., Yurak V. V. 2017, Problemy razrabotki i realizatsii megaproyekta "Ural Promyshlennyy - Ural Polyarnyy»: uroki dlya budushchego [Problems of development and implementation of the megaproject "Ural Industrial - Ural Polar": lessons for the future]. EKO [ECO], no. 9, pp. 42-53.

17. Zakharchuk E. A., Pasynkov A. F. 2016, Rossiyskaya Arktika: otsenka i vozmozhnosti finansovogo razvitiya [The Russian Arctic: assessment and the possibility of financial development]. EKO [ECO], no. 5 (503), pp. 107-119. 


\title{
Минераиьно-сырьевая база Ураиьского фелераиьного округа: на пути к сбалансированному недропользованию (на примере твердых полезных ископаемых)
}

\author{
Ирина Геннадьевна Полянская ${ }^{1}$, \\ irina-pol2004@mail.ru \\ Сергей Александрович Рыльков ${ }^{2,3}$ \\ ural@rosnedra.gov.ru \\ Вера Васильевна Юрак ${ }^{1,3}$, \\ vera_yurak@mail.ru \\ Владимир Викторович Масленников ${ }^{1}$ \\ maslennikov.1950@mail.ru
}

\author{
1 Институт экономики УрО РАН \\ Россия, Екатеринбург \\ ²Департамент по недропользованию по Уральскому \\ федеральному округу (Уралнедра) \\ Россия, Екатеринбург \\ зУральский государственный горный университет \\ Россия, Екатеринбург
}

\begin{abstract}
Актуацьность. Процесс сбалансированного использования минерально-сырьевых ресурсов, представляюший собой одно из приоритетных направлений как воспроизводства и добычи природных ресурсов, так и государственной политики в области национальной безопасности, имеет особое значение. В настоящее время перед органами государственного регулирования недропользования стоит ряд насушных проблем: во-первых, затрудняется процесс возмещения истощившихся запасов твердых полезных ископаемых (ТПИ), а во-вторых, мировое вхождение в шестой технологический укиац и набираюшая силу «четвертая промышленная революция" Аиктуют условия организации сбалансированного недропользования, которое подразумевает достижение баманса общих факторов развития (ресурсный, «зеленый", социамьный, экономический) при использовании высоких технологий, устройств искусственного интемекта, робототехники и Аругих инновационных решений. В целях реализации сбалансированного неАропользования в региональном и страновом масштабах в первую очередь необходимо проведение диагностики состояния минераиьно-сырьевой базы (МСБ). Аанная оценка сможет стать функциональным инструментом государственного регулирования недропользования.

Цель работы - анаяиз состояния минерально-сырьевой базы недропользования Ураяьского федерального округа (УрФО) с точки зрения выполнения условия сбалансированности (обеспеченности).

Результаты. Определен базовый принцип - условие достижения сбалансированности недропользования; выявлены специсрика и проблемы в управлении немропользованием УрФО на основе анаяиза МСБ УрФО и системы финансирования геологоразведочных работ в УрФО; идентифицированы возможные направления выполнения условия достижения сбалансированности.

Выводы. Истошенность МСБ ТПИ округа и приоритетность Аобычи топливно-энергетического сырья способствуют снижению федерального финансирования на развитие МСБ ТПИ УрФО. НеАропользователи округа, в той или иной степени обеспеченные запасами, не заинтересованы в проведении дальнейших поисковых работ. Изложенное свидетельствует о необходимости разработки и внедрения взвешенных решений по проведению Аальнейшего стацийного геологического изучения МСБ ТПИ в рамках государственно-частного партнерства с использованием механизмов отраслевого регулирования в целях Аостижения сбалансированного обеспечения продуцентов округа собственным сырьем.
\end{abstract}

Киючевые слова: минерально-сырьевая база, твердые полезные ископаемые, УрФО, воспроизводство, геологоразведочные работы, сбалансированное недропользование, обеспеченность.

Исследование подготовлено при финансовой поддержке Проекта РАН № 18-6-7-42 «Социально-экономическое развитие Арктической зоны Урала: потенииальные возможности, приоритеты и перспективы пространственного освоения».

\section{ЛИТЕРАТУРА}

1. Tjiptabudy J. The application of the balance principal in the natural resources management in marine and coastal areas // Mimbar Hukum. 2014 . № 26 (2). P. 285-296.

2. Herbohn K., Herbohn J., Hartebrodt C., Smith C. Using a Balanced Scorecard to Improve the Management of Natural Resources: Experiences from Baden-Württemberg // Society \& Natural Resources: An International Journal. 2013. № 26 (8). P. 865-882. DOI: 10.1080/08941920.2012.719999. 3. Marimin M., Wibisono A., Darmawan M. A. Decision Support System for Natural Rubber Supply Chain Management Performance Measurement: A Sustainable Balanced Scorecard Approach // International Journal of Supply Chain Management. 2017. № 6 (2). P. $60-74$.

4. Connell J. Islands: balancing development and sustainability? // Environmental Conservation. 2018. P. 1-14. DOI: 10.1017/S0376892918000036. 5. Reilly J. M. Green Growth and the Efficient Use of Natural Resources // Energy Economics. 2012. № 34. P. 85-93.

6. Наталенко А. Е., Пак В. А., Ставский А. П. Основные направления развития минерально-сырьевой базы Российской Федерации // Минеральные ресурсы России. Экономика и управление. 2015. № 1. С. 2-9.

7. Карпузов А. Ф., Тарасов А. В. Стратегические векторы развития минерально-сырьевой базы Российской Федерации на современном этапе (выбор пути) // Минеральные ресурсы России. Экономика и управление. 2015. № 6. С. 2-12.

8. Рыльков С. А. Природно-ресурсный потенциал Уральского ФО // Разведка и охрана недр. 2016. № 9. С. 30-33.

9. Парфенов С. А. Север надо писать с большой буквы // Урал. 2009. № 8. С. 204-212.

10. Министерство природных ресурсов и экологии РФ. Федеральное агентство по недропользованию. Итоги работы Федерального агентства по недропользованию в 2016 году и планы на 2017 год: информационно-аналитические материалы. М.: Минерал-Инфо, 2017. 58 с.

11. Иванов А. И., Вартанян С. С., Черных А. И., Волчкова А. Г., Кузнецов В. В., Серавина Т. В. Состояние и перспективы развития МСБ меди, цинка и свинца России // Разведка и охрана недр. 2016. № 9. С. 95-100.

12. Михайлов Б. К. Основные приоритеты и показатели развития минерально-сырьевой базы твердых полезных ископаемых в стратегических документах геологической отрасли // Минеральные ресурсы России. Экономика и управление. 2016. № 5. С. 25-29.

13. Мелехин Е. С., Дудуков М. В. Правовые проблемы привлечения инвестиций в воспроизводство минерально-сырьевой базы страны // Минеральные ресурсы России. Экономика и управление. 2016. № 1 (1). С. 80-82.

14. Агеева С. Д., Крюков В. А. Система недропользования в России - какой ей быть? // Минеральные ресурсы России. Экономика и управление. 2016. № 2. С. 80-87.

15. Михайлов Б. К. Роль государства в развитии минерально-сырьевой базы твердых полезных ископаемых в стратегических документах геологической отрасли // Минеральные ресурсы России. Экономика и управление. 2017. № 2. С. 33-35.

16. Душин А. В., Юрак В. В. Проблемы разработки и реализации мегапроекта «Урал Промышленный - Урал Полярный»: уроки для будущего // ЭКО. 2017. № 9. С. 42-53.

17. Захарчук Е. А., Пасынков А. Ф. Российская Арктика: оценка и возможности финансового развития // ЭКО. 2016. № 5 (503). С. 107-119. 